\title{
Preparation and machine-learning methods of nacre-like composites from self-assembly of magnetic colloids exposed to rotating magnetic fields
}

Joelle Medinger ${ }^{a}$, Miroslava Nedyalkova ${ }^{a}$, Marco Furlan ${ }^{a, b}$, Thomas Lüthi ${ }^{c}$, Jürgen Hofmann $^{c}$, Antonia Neels ${ }^{a, c}$ and Marco Lattuada ${ }^{a^{*}}$

${ }^{a}$ University of Fribourg, Department of Chemistry, Chemin du Musée 9, CH-1700 Fribourg, Switzerland.

${ }^{\mathrm{b}} \mathrm{eCO}_{2} \mathrm{SA}$, Via Brüsighell 6, 6807 Taverne, Switzerland

${ }^{\mathrm{c}}$ Empa, Center for X-Ray Analytics, Überlandstrasse 129, CH-8600 Dübendorf, Switzerland

*Email: marco.lattuada@unifr.ch
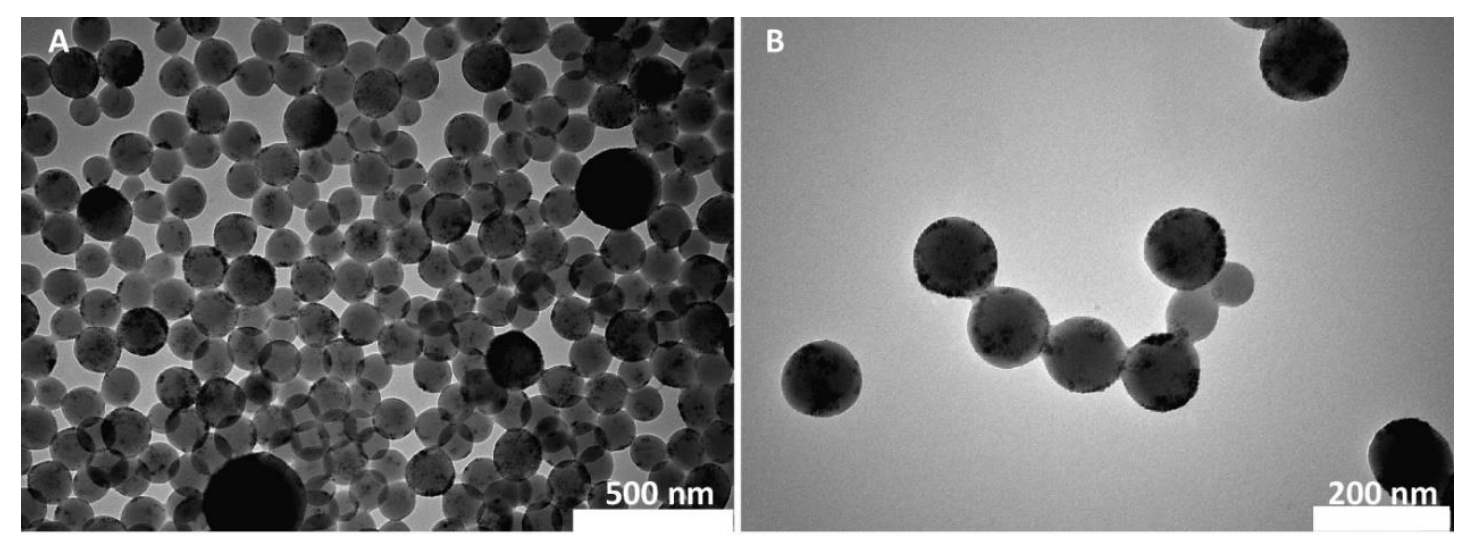

Figure S1. TEM images of magnetic polystyrene beads. (A) Spherical polystyrene beads containing magnetite with average size of $150 \mathrm{~nm}$. (B) Magnetite is located primarily at the surface of the polystyrene beads. 

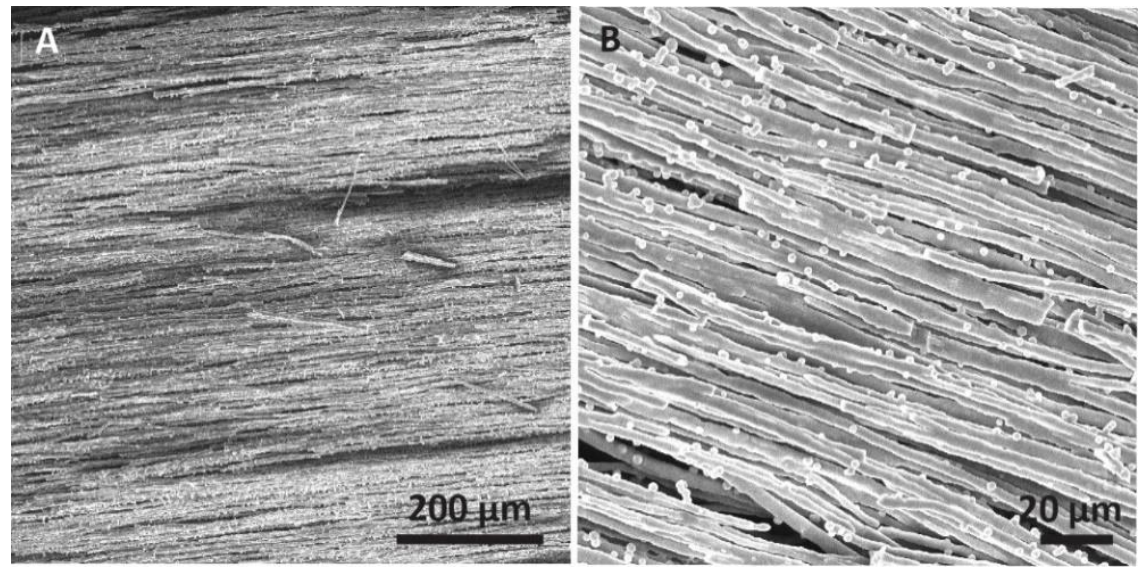

Figure S2. SEM image of rod-like structure of silica monolith obtained by application of a uniform magnetic field during sol-gel process.
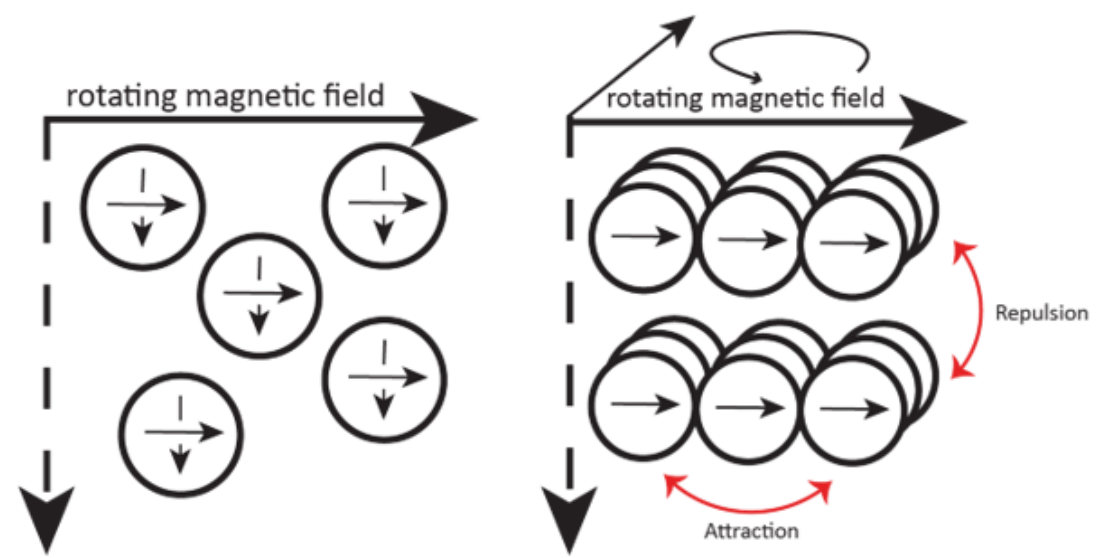

$\sum$ attractive and repulsive forces = attractive forces dominate (horizontally)

Figure S3. Schematic illustration of the forces acting on the superparamagnetic colloids when a high frequency rotating magnetic field is applied. 

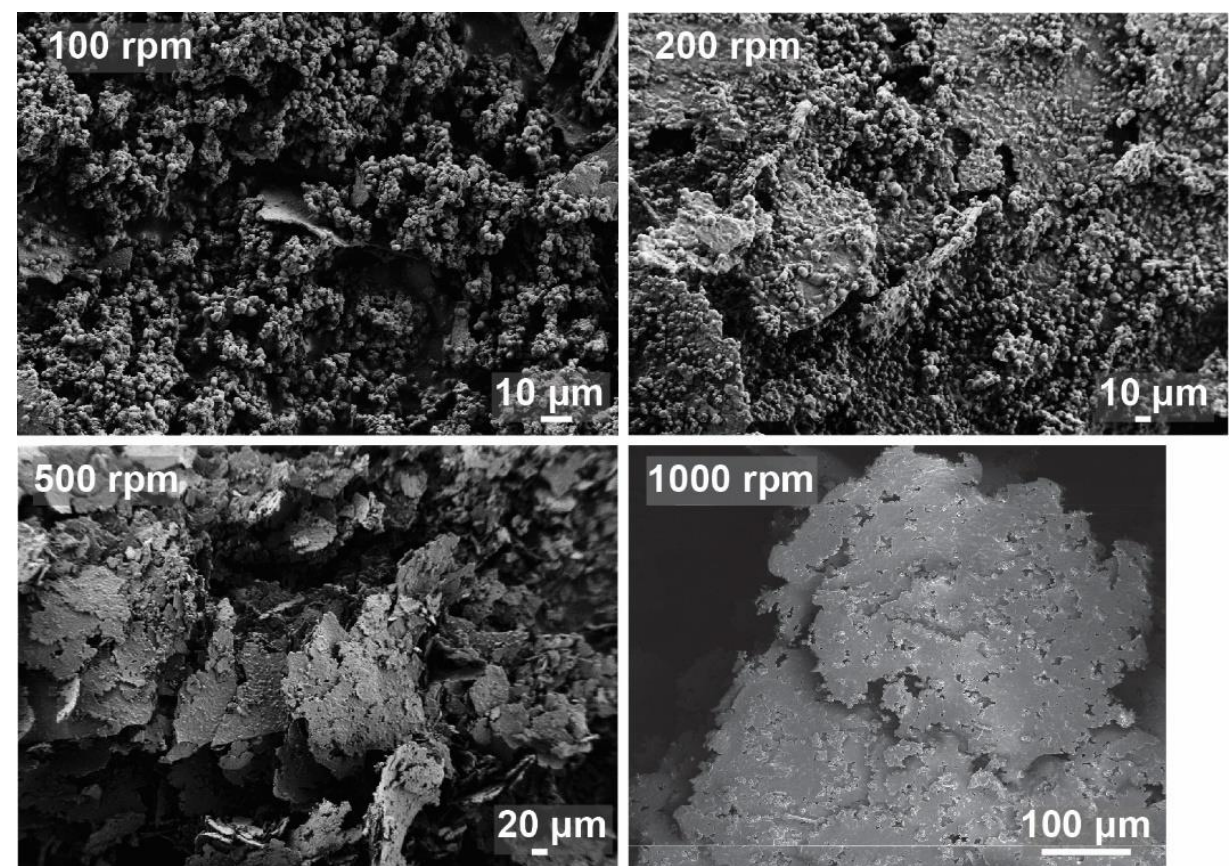

Figure S4. SEM images of samples prepared at 100, 200, 500 and $1000 \mathrm{rpm}$ rotation speed. At higher rotation speed, the self-organization into platelet-like structure is complete.
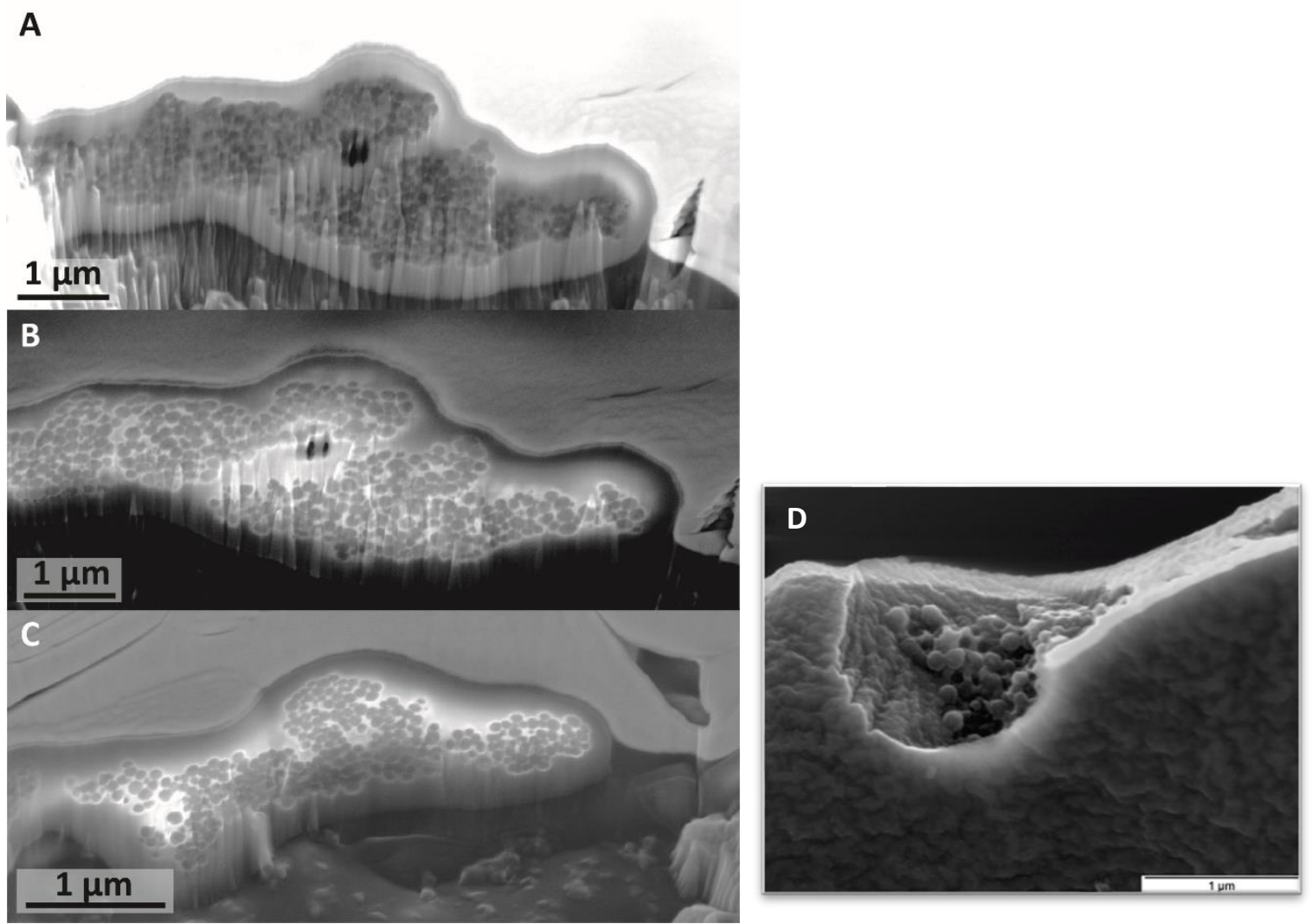

Figure S5. (a)-(C) FIB cross-section of the platelet structure, clearly showing the magnetic colloids organized in layers, inside the silica matrix. (D) SEM image of the magnetite colloids which are completely embedded in silica during the sol-gel process. 

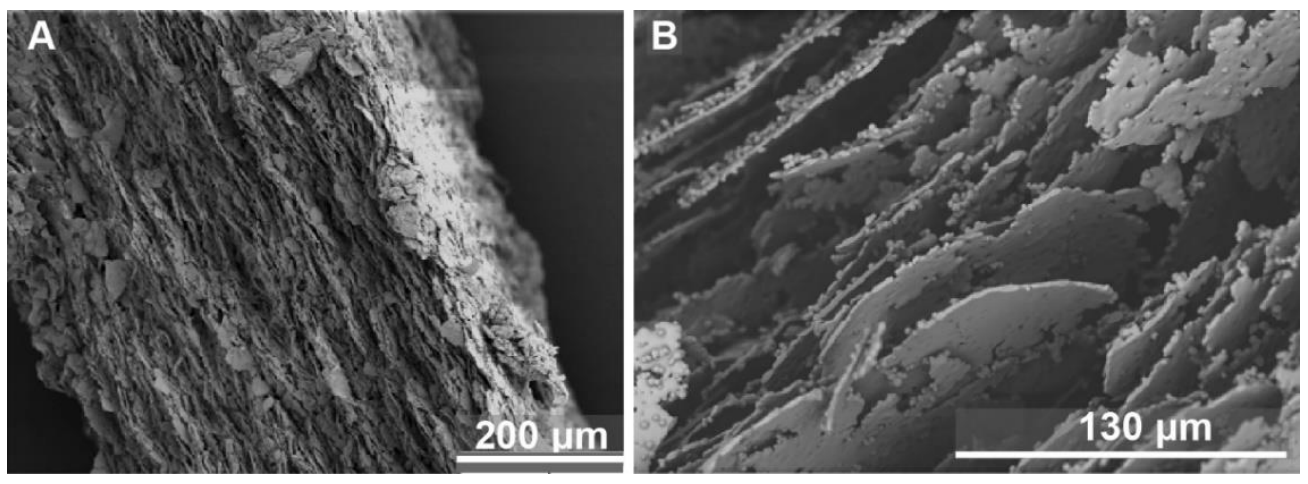

Figure S6. The silica platelets are interconnected with each other and form multiple layers, which pile up upon each other. 
Table S1. BET data for silica samples without added magnetic particles, isotropic monoliths containing magnetic nanoparticles but without application of a magnetic field during sol-gel transition and platelet-structured monoliths. All samples were submitted to a heat-treatment at $600{ }^{\circ} \mathrm{C}$ and $850^{\circ} \mathrm{C}$ and were again measured to see the change in porosity. Closure of other pores at higher temperature gives as result a smaller internal surface as compared to the $600^{\circ} \mathrm{C}$ heat-treated samples.

\begin{tabular}{|c|c|c|c|c|}
\hline \multirow[t]{2}{*}{ Sample } & \multirow[t]{2}{*}{$\mathrm{S}_{\text {BET }}\left(\mathbf{m}^{2} / \mathrm{g}\right)$} & \multirow[t]{2}{*}{$V_{\text {BET }}\left(\mathrm{cm}^{3} / \mathrm{g}\right)$} & \multicolumn{2}{|c|}{$\begin{array}{l}\text { Pore diameter } \\
\text { (Angstroem) }\end{array}$} \\
\hline & & & adsorption & desorption \\
\hline Silica (no NPs) & 3.67 & 0.016 & 170.78 & 176.17 \\
\hline Isotropic & 1.86 & 0.004 & 85.32 & 85.32 \\
\hline Platelet & 1.26 & 0.003 & 88.07 & 90.66 \\
\hline Silica $600{ }^{\circ} \mathrm{C}$ (no NPs) & 401.54 & 0.41 & 41.03 & 41.03 \\
\hline Isotropic $600{ }^{\circ} \mathrm{C}$ & 471.91 & 0.38 & 3.19 & 3.19 \\
\hline Platelet $600^{\circ} \mathrm{C}$ & 632.47 & 0.43 & 26.89 & 26.88 \\
\hline Silica $850^{\circ} \mathrm{C}$ (no NPs) & 44.76 & 0.20 & 175.86 & 175.86 \\
\hline Isotropic $850^{\circ} \mathrm{C}$ & 57.11 & 0.17 & 199.30 & 122.11 \\
\hline Platelet $800^{\circ} \mathrm{C}$ & 344.52 & 0.25 & 29.38 & 29.38 \\
\hline $\begin{array}{l}\text { Platelet composite } \\
\text { (polymerized) }\end{array}$ & 0.37 & 0.001 & 68.31 & 68.31 \\
\hline
\end{tabular}

Table S2. Data of shrinkage observed after the heat-treatment of monoliths at $600{ }^{\circ} \mathrm{C}$ and 850 ${ }^{\circ} \mathrm{C}$. H stands for height, L for length and B for width. "Initial" indicates the initial size of the block before the heat-treatment and "final" is the final size of the block after the heat-treatment. The average shrinkage observed for the heat-treated blocks at $600{ }^{\circ} \mathrm{C}$ is $10.85 \%$ of total volume and $16 \%$ for $850{ }^{\circ} \mathrm{C}$.

\begin{tabular}{|c|c|c|c|c|c|c|c|c|c|}
\hline \multirow{2}{*}{$\begin{array}{l}600{ }^{\circ} \mathbf{C} \\
\text { Platelet } 1\end{array}$} & \multirow[b]{2}{*}{ initial } & \multirow[b]{2}{*}{ final } & \multirow[b]{2}{*}{$\Delta \mathrm{l}$} & \multirow[b]{2}{*}{$\%$ shrinkage } & \multicolumn{2}{|l|}{$850{ }^{\circ} \mathrm{C}$} & \multirow[b]{2}{*}{ final } & \multirow[b]{2}{*}{$\Delta \mathrm{l}$} & \multirow[b]{2}{*}{$\%$ shrinkage } \\
\hline & & & & & Platelet 8 & initial & & & \\
\hline $\mathrm{H}$ & 20 & 19.62 & 0.38 & 1.9 & $\mathrm{H}$ & 23.2 & 18.25 & 4.95 & 21.34 \\
\hline $\mathrm{L}$ & 21.2 & 20.4 & 0.8 & 3.77 & $\mathrm{~L}$ & 23.5 & 18.5 & 5 & 21.28 \\
\hline B & 21 & 20 & 1 & 4.76 & B & 23.6 & 19.7 & 3.9 & 16.53 \\
\hline Platelet 2 & initial & final & $\Delta \mathrm{l}$ & $\%$ shrinkage & Platelet 9 & initial & final & $\Delta \mathrm{l}$ & $\%$ shrinkage \\
\hline $\mathrm{H}$ & 22.7 & 19.5 & 3.2 & 14.10 & $\mathrm{H}$ & 21 & 15.6 & 5.4 & 25.71 \\
\hline $\mathrm{L}$ & 22 & 19.2 & 2.8 & 12.73 & $\mathrm{~L}$ & 23 & 18.8 & 4.2 & 18.26 \\
\hline B & 22 & 19.2 & 2.8 & 12.73 & B & 23 & 18.9 & 4.1 & 17.83 \\
\hline Platelet 3 & initial & final & $\Delta \mathrm{l}$ & $\%$ shrinkage & Platelet 10 & initial & final & $\Delta \mathrm{l}$ & $\%$ shrinkage \\
\hline $\mathrm{H}$ & 21.7 & 19.2 & 2.5 & 11.52 & $\mathrm{H}$ & 21.5 & 17.65 & 3.85 & 17.91 \\
\hline $\mathrm{L}$ & 21.3 & 18.5 & 2.8 & 13.15 & $\mathrm{~L}$ & 22.3 & 18.23 & 4.07 & 18.25 \\
\hline B & 21 & 18 & 3 & 14.29 & B & 22 & 18.25 & 3.75 & 17.05 \\
\hline Platelet 4 & initial & final & $\Delta \mathrm{l}$ & $\%$ shrinkage & Platelet 11 & initial & final & $\Delta \mathrm{l}$ & $\%$ shrinkage \\
\hline $\mathrm{H}$ & 16.5 & 14.8 & 1.7 & 10.30 & $\mathrm{H}$ & 16.75 & 14.2 & 2.55 & 15.22 \\
\hline $\mathrm{L}$ & 9.1 & 8.3 & 0.8 & 8.79 & $\mathrm{~L}$ & 9.1 & 7.8 & 1.3 & 14.29 \\
\hline B & 9.1 & 8.2 & 0.9 & 9.89 & B & 9.1 & 7.8 & 1.3 & 14.29 \\
\hline Platelet 5 & initial & final & $\Delta \mathrm{l}$ & $\%$ shrinkage & Platelet 12 & initial & final & $\Delta \mathrm{l}$ & $\%$ shrinkage \\
\hline $\mathrm{H}$ & 16.5 & 14.7 & 1.8 & 10.91 & $\mathrm{H}$ & 16.73 & 14 & 2.73 & 16.32 \\
\hline $\mathrm{L}$ & 9 & 8.2 & 0.8 & 8.89 & $\mathrm{~L}$ & 9 & 7.6 & 1.4 & 15.56 \\
\hline
\end{tabular}




\begin{tabular}{|c|c|c|c|c|c|c|c|c|c|}
\hline B & 9 & 8.2 & 0.8 & 8.89 & B & 9 & 7.7 & 1.3 & 14.44 \\
\hline Platelet 6 & initial & final & $\Delta \mathrm{l}$ & $\%$ shrinkage & Platelet 13 & initial & final & $\Delta \mathrm{l}$ & $\%$ shrinkage \\
\hline $\mathrm{H}$ & 17 & 15.2 & 1.8 & 10.59 & $\mathrm{H}$ & 16.73 & 14.1 & 2.63 & 15.72 \\
\hline $\mathrm{L}$ & 9.1 & 8.2 & 0.9 & 9.89 & $\mathrm{~L}$ & 8.9 & 7.7 & 1.2 & 13.48 \\
\hline B & 9 & 8.3 & 0.7 & 7.78 & $\mathrm{~B}$ & 9.1 & 7.8 & 1.3 & 14.29 \\
\hline Platelet 7 & initial & final & $\Delta \mathrm{l}$ & $\%$ shrinkage & Platelet 14 & initial & final & $\Delta \mathrm{l}$ & $\%$ shrinkage \\
\hline $\mathrm{H}$ & 16.8 & 15 & 1.8 & 10.71 & $\mathrm{H}$ & 16.7 & 14.2 & 2.5 & 14.97 \\
\hline $\mathrm{L}$ & 9 & 8.15 & 0.85 & 9.44 & $\mathrm{~L}$ & 8.9 & 7.7 & 1.2 & 13.48 \\
\hline B & 9 & 8.15 & 0.85 & 9.44 & B & 8.9 & 7.8 & 1.1 & 12.36 \\
\hline Random 1 & initial & final & $\Delta \mathrm{l}$ & $\%$ shrinkage & Random 4 & initial & final & $\Delta \mathrm{l}$ & $\%$ shrinkage \\
\hline $\mathrm{H}$ & 14 & 12.8 & 1.2 & 8.57 & $\mathrm{H}$ & 13.5 & 11.5 & 2 & 14.81 \\
\hline $\mathrm{L}$ & 21.32 & 19 & 2.32 & 10.88 & $\mathrm{~L}$ & 21.5 & 18.21 & 3.29 & 15.30 \\
\hline B & 21.36 & 19 & 2.36 & 11.05 & B & 20.7 & 18.3 & 2.4 & 11.59 \\
\hline Random 2 & initial & final & $\Delta \mathrm{l}$ & $\%$ shrinkage & Random 5 & initial & final & $\Delta \mathrm{l}$ & $\%$ shrinkage \\
\hline $\mathrm{H}$ & 13.9 & 12.5 & 1.4 & 10.07 & $\mathrm{H}$ & 13.9 & 11.6 & 2.3 & 16.55 \\
\hline $\mathrm{L}$ & 21.3 & 19 & 2.3 & 10.80 & $\mathrm{~L}$ & 21.5 & 18.71 & 2.79 & 12.98 \\
\hline B & 21 & 19.3 & 1.7 & 8.10 & B & 21.2 & 18.16 & 3.04 & 14.34 \\
\hline Random 3 & initial & final & $\Delta \mathrm{l}$ & $\%$ shrinkage & \multirow{4}{*}{\multicolumn{2}{|c|}{$\begin{array}{c}\text { Total shrinkage \% } \\
600{ }^{\circ} \mathrm{C} \\
10.85\end{array}$}} & \multirow{4}{*}{\multicolumn{3}{|c|}{$\begin{array}{c}\text { Total shrinkage \% } \\
850{ }^{\circ} \mathrm{C} \\
16.08\end{array}$}} \\
\hline $\mathrm{H}$ & 13.5 & 12.3 & 1.2 & 8.89 & & & & & \\
\hline $\mathrm{L}$ & 25.6 & 19 & 6.6 & 25.78 & & & & & \\
\hline B & 26 & 19 & 7 & 26.92 & & & & & \\
\hline
\end{tabular}


A

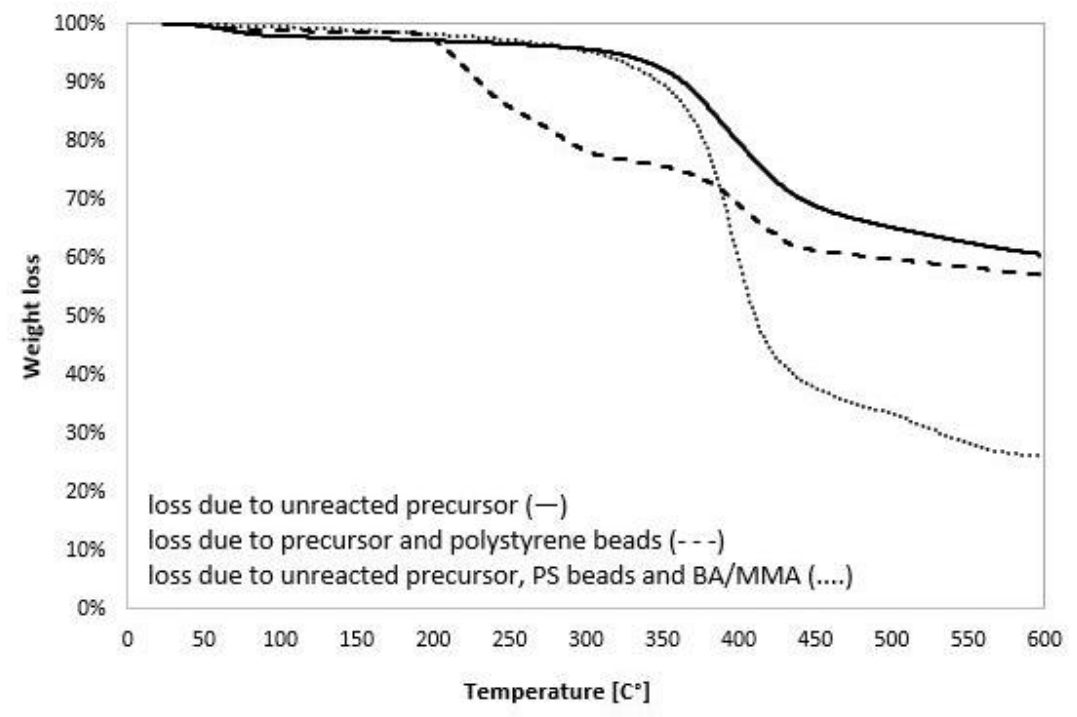

B

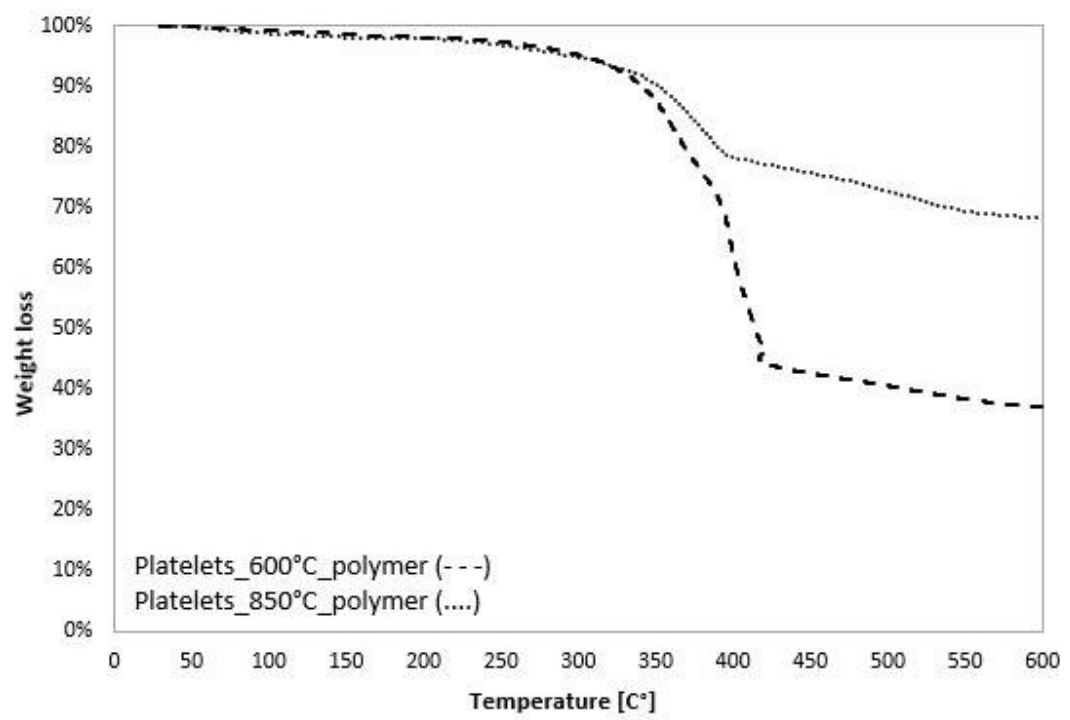

Figure S7. TGA graphs of monoliths containing only magnetic colloids and monoliths containing magnetic colloids and filled with polymer. (A) TGA graph of a pure silica monolith containing no magnetic template and no polymer. It becomes clear that a certain amount of unreacted precursor is contained in the monolith. The data shows $40 \%$ of weight loss by burning unreacted precursor and the polystyrene of the magnetic beads. If the platelet-structured monolith is filled additionally with polymer, the weight loss increases to $65 \% .40 \%$ are due to the polystyrene and precursor while $25 \%$ of weight loss are due to the polymer, which is burned. B) In the case of heat-treated samples, the precursor and template are already burned out and the internal area can be completely occupied by the polymer. Heat-treatment at $600{ }^{\circ} \mathrm{C}$ causes partial pore shrinkage of $11 \%$; the weight loss is $60 \%$ when the polymer filling is burned away. At $850{ }^{\circ} \mathrm{C}$ the TGA data confirms the $25 \%$ of polymer content of BA/MMA that can be filled by impregnating the monolith with monomer solution. 

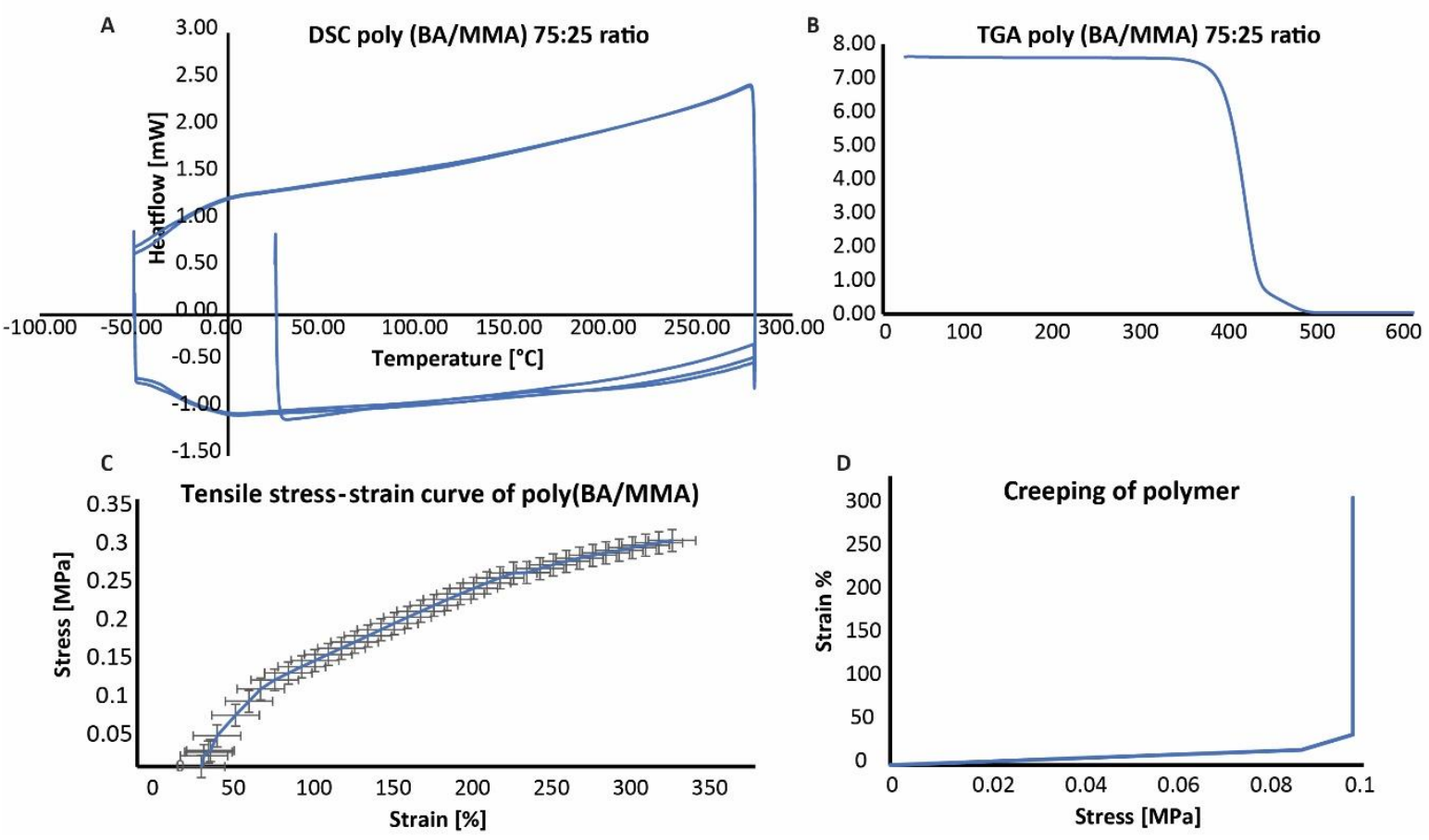

Figure S8. Characterization of the added polymer to form the desired composite. (A) DSC was used to confirm that the polymer is amorphous. The polymer was tested between -50 and 280 ${ }^{\circ} \mathrm{C}$ and shows low $\mathrm{t}_{\mathrm{g}}$ of around $-25^{\circ} \mathrm{C}$, (C) TGA shows decomposition temperature above 400 ${ }^{\circ} \mathrm{C}$. (C) Tensile tests show that the polymer is amorphous and creeps very easily. (D) By a fixed stress of $0.1 \mathrm{MPa}$, the strain increased continuously, confirming the creeping property of the polymer. The polymer shows itself ideal to increase the toughness of the monoliths. 

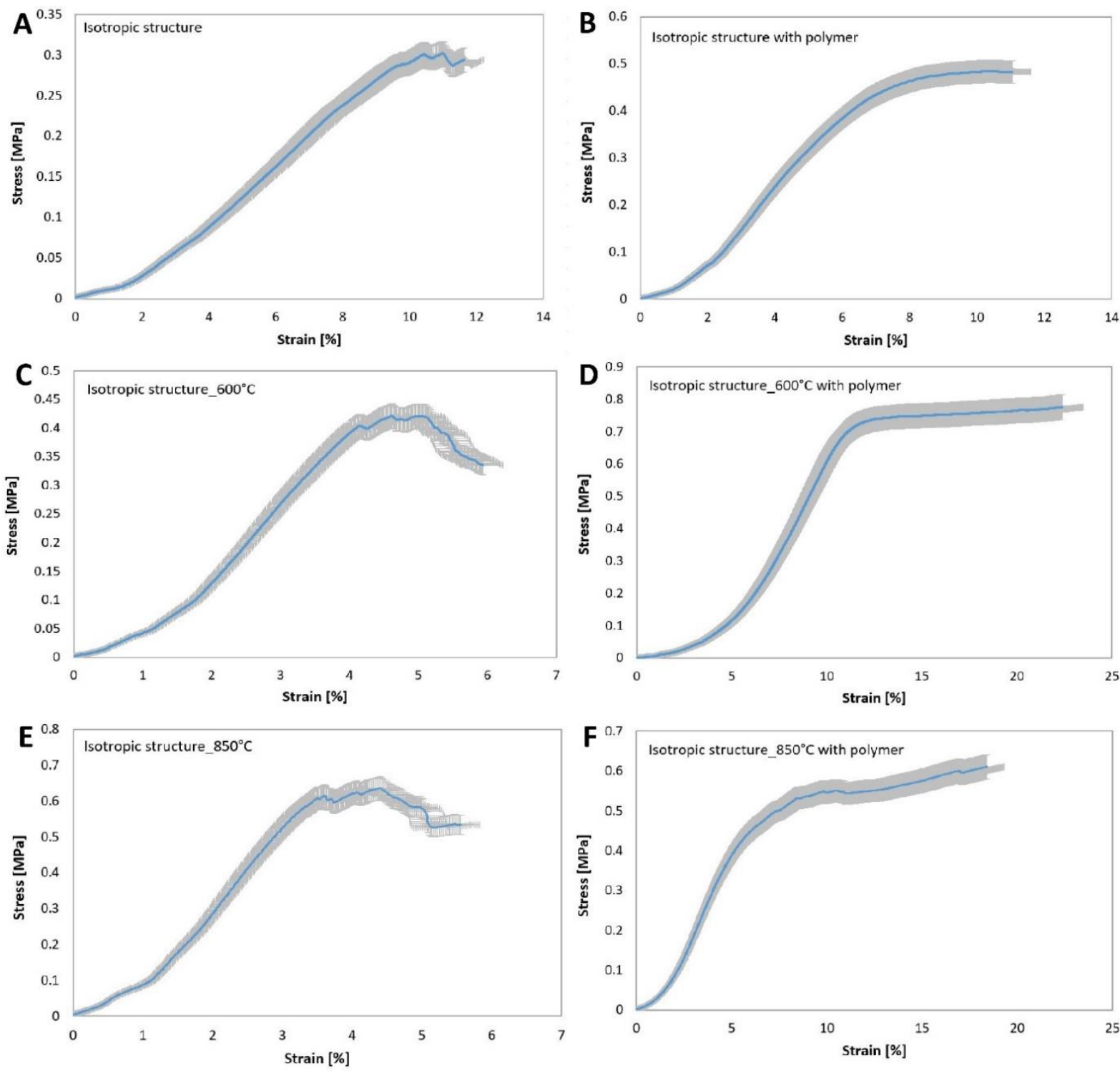

Figure S9. Stress-strain curves of uniaxial compression tests of isotropic structured silica monoliths. (A) Without and (B) with polymer. (C) With heat-treatment at $600{ }^{\circ} \mathrm{C}$ and (D) heattreatment at $600{ }^{\circ} \mathrm{C}$ followed by composite formation through addition of polymer. (E) Heattreatment at $850{ }^{\circ} \mathrm{C}$ and $(\mathrm{F})$ heat-treatment at $850{ }^{\circ} \mathrm{C}$ followed by the addition of polymer. 

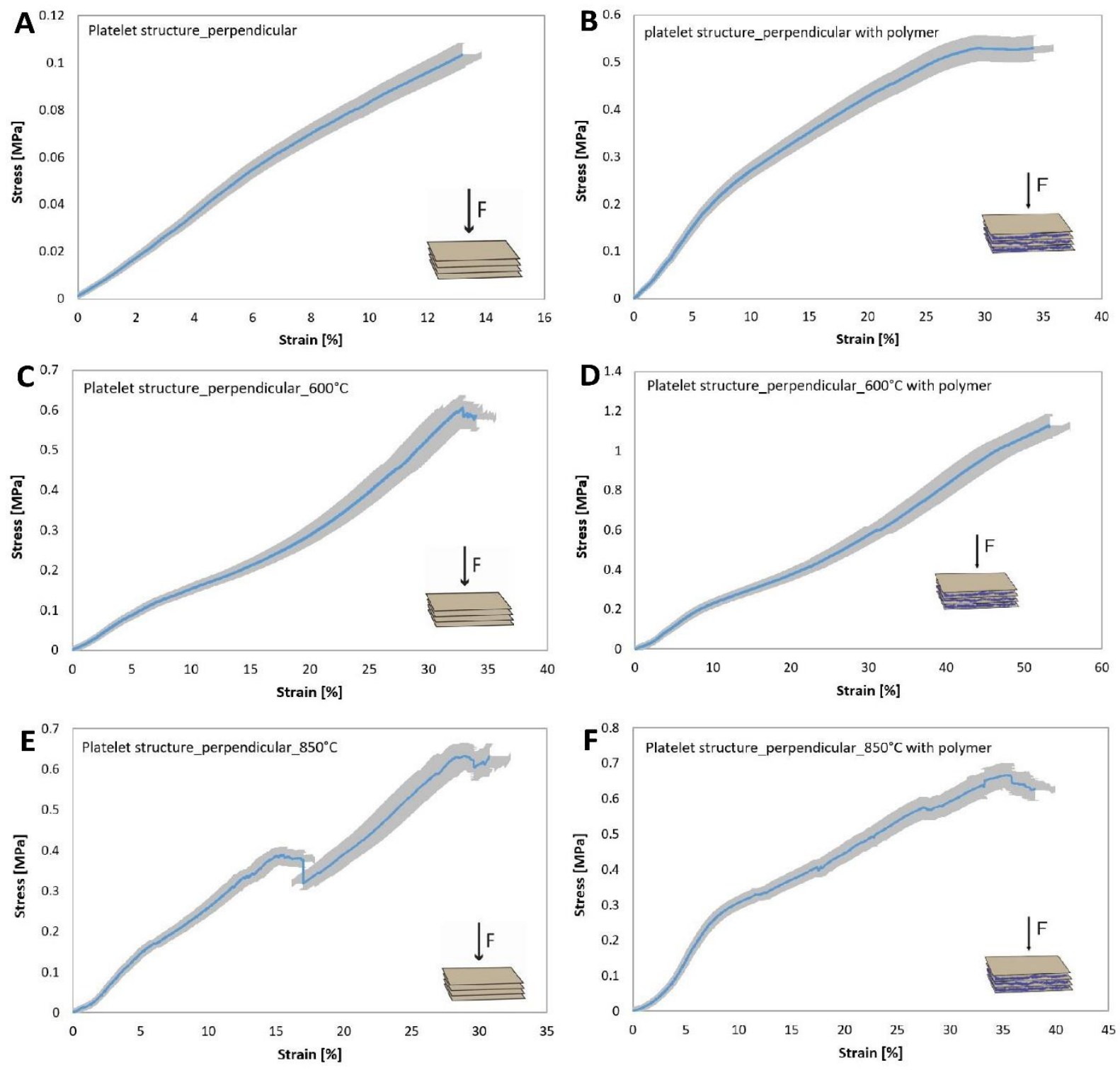

Figure S10. Stress-strain curves of uniaxial compression tests of nacre-like platelet structured silica monoliths. (A) Without and (B) with polymer. (C) With heat-treatment at $600{ }^{\circ} \mathrm{C}$ and (D) heat-treatment at $600{ }^{\circ} \mathrm{C}$ followed by composite formation through addition of polymer. (E) Heat-treatment at $850^{\circ} \mathrm{C}$ and $(\mathrm{F})$ heat-treatment at $850^{\circ} \mathrm{C}$ followed by the addition of polymer. The orientation of the platelet structure was perpendicular to the uniaxial compression force as shown in the cartoon in the graphs. 

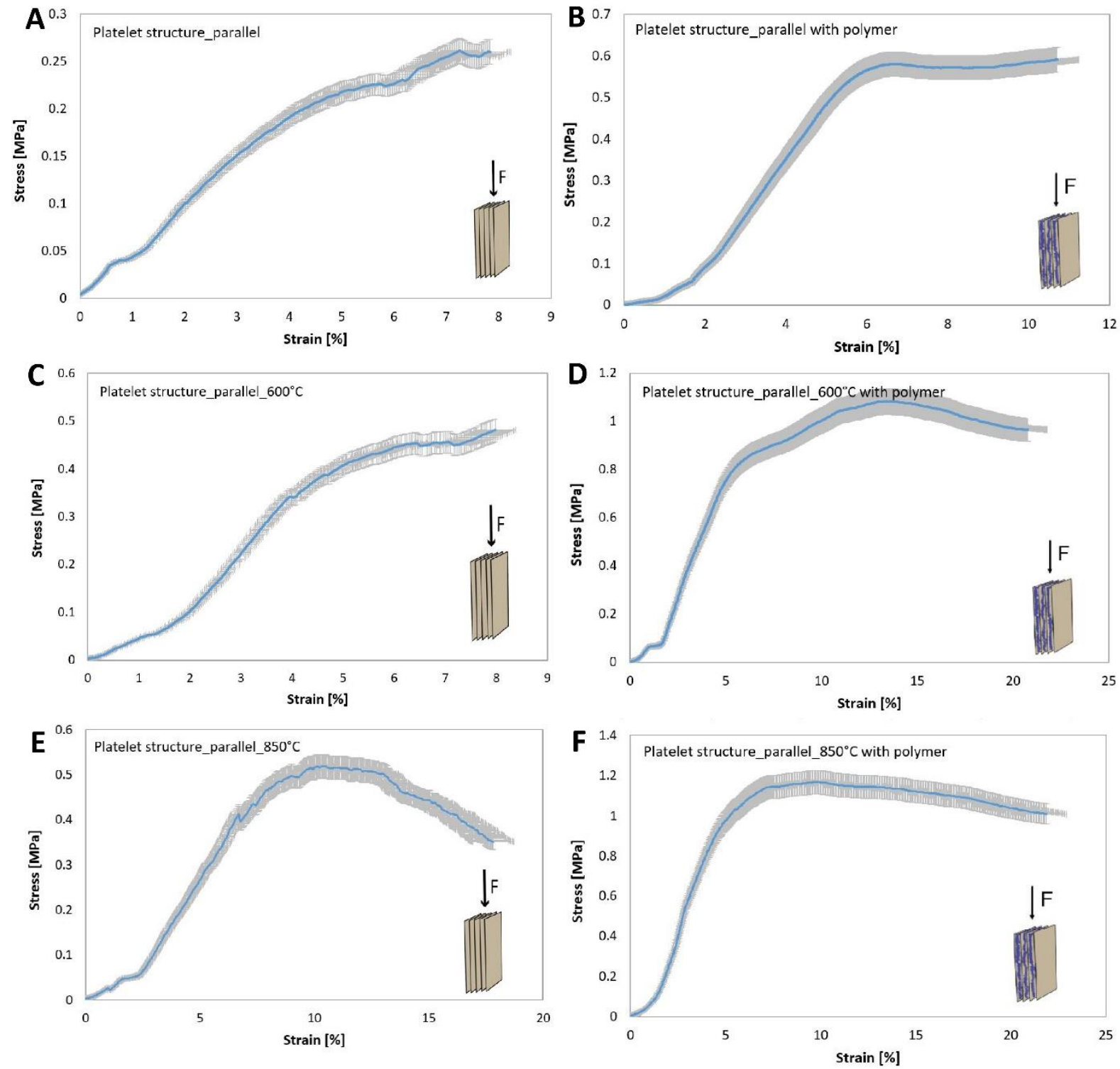

Figure S11. Stress-strain curves of uniaxial compression tests of nacre-like platelet structured silica monoliths. (A) Without and (B) with polymer. (C) With heat-treatment at $600{ }^{\circ} \mathrm{C}$ and (D) heat-treatment at $600{ }^{\circ} \mathrm{C}$ followed by composite formation through addition of polymer. (E) Heat-treatment at $850^{\circ} \mathrm{C}$ and $(\mathrm{F})$ heat-treatment at $850{ }^{\circ} \mathrm{C}$ followed by the addition of polymer. The orientation of the platelet structure was parallel to the uniaxial compressive force as shown in the cartoon in the graphs.

Table S3. Numerical data of toughness used to generate the bar graphs.

\begin{tabular}{ll}
\hline isotropic & 0.034 \\
\hline platelet_parallel & 0.068 \\
\hline platelet_perpendicular & 0.071 \\
\hline isotropic polymer & 0.148 \\
\hline platelet polymer_parallel & 0.294 \\
\hline platelet polymer_perpendicular & 0.242 \\
\hline isotropic $600{ }^{\circ} \mathrm{C}$ & 0.027 \\
\hline platelet $600{ }^{\circ} \mathrm{C} \_$parallel & 0.107 \\
\hline platelet $600{ }^{\circ} \mathrm{C} \_$perpendicular & 0.171 \\
\hline isotropic $600{ }^{\circ} \mathrm{C}$ polymer & 0.401
\end{tabular}




\begin{tabular}{ll}
\hline platelet $600{ }^{\circ} \mathrm{C}$ polymer_parallel & 0.451 \\
\hline platelet $600{ }^{\circ} \mathrm{C}$ polymer_perpendicular & 0.339 \\
\hline isotropic $850{ }^{\circ} \mathrm{C}$ & 0.035 \\
\hline platelet $850{ }^{\circ} \mathrm{C}$ _parallel & 0.133 \\
\hline platelet $850{ }^{\circ} \mathrm{C}$ _perpendicular & 0.172 \\
\hline isotropic $850{ }^{\circ} \mathrm{C}$ polymer & 0.237 \\
\hline platelet $8500^{\circ} \mathrm{C}$ polymer_parallel & 0.330 \\
\hline platelet $8500^{\circ} \mathrm{C}$ polymer_perpendicular & 0.312 \\
\hline
\end{tabular}
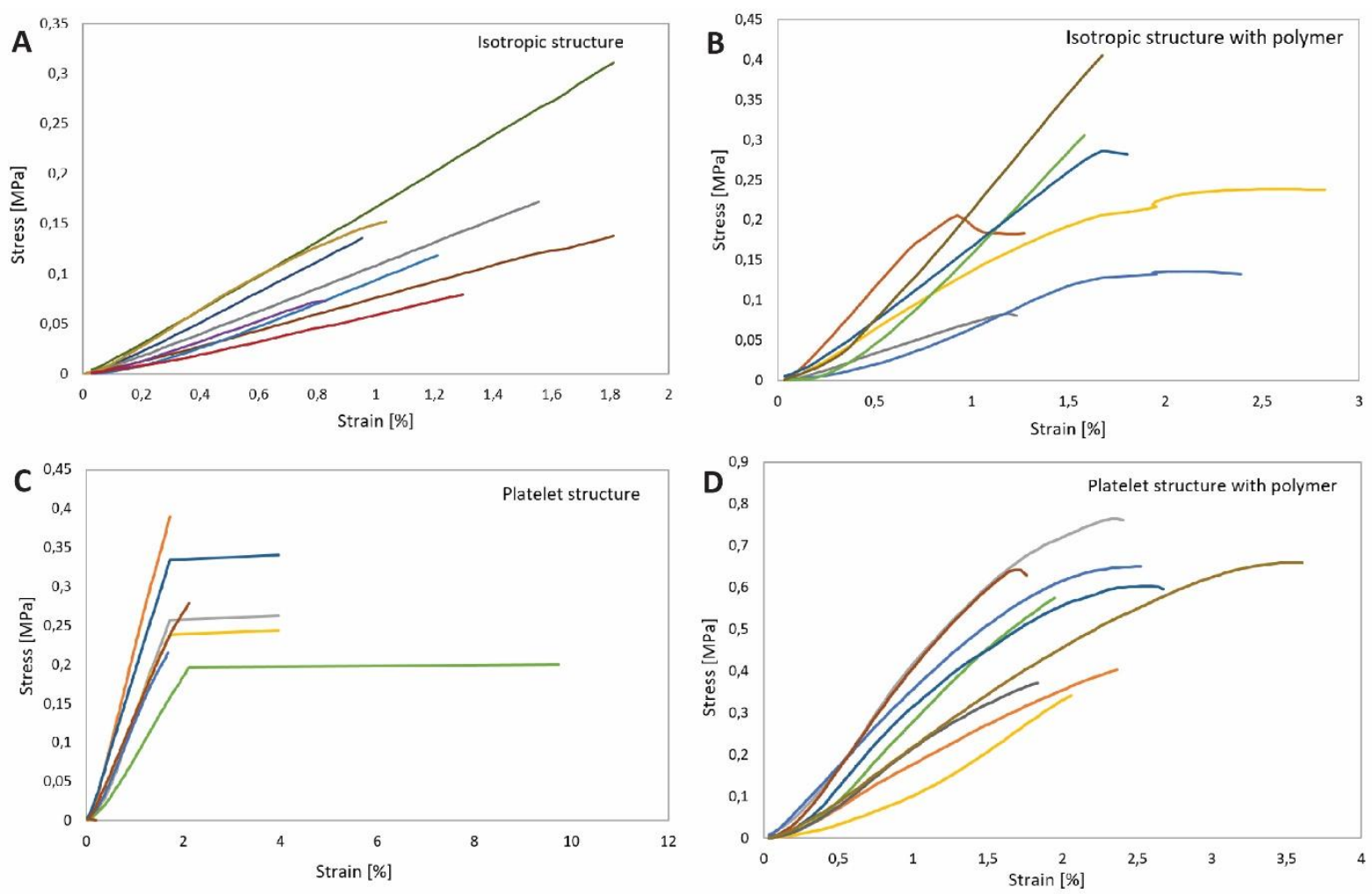

Figure S12. Stress-strain curves of all samples measured with dynamic mechanical testing. (A) Stress-strain curves of isotropic structured samples (B) stress-strain curves of isotopically structured samples filled with polymer. (C) Stress-strain curves of all perpendicular oriented, mimicking nacre, platelet-structured samples and (D) stress- strain curves of perpendicularly oriented platelet structured samples filled with polymer. 


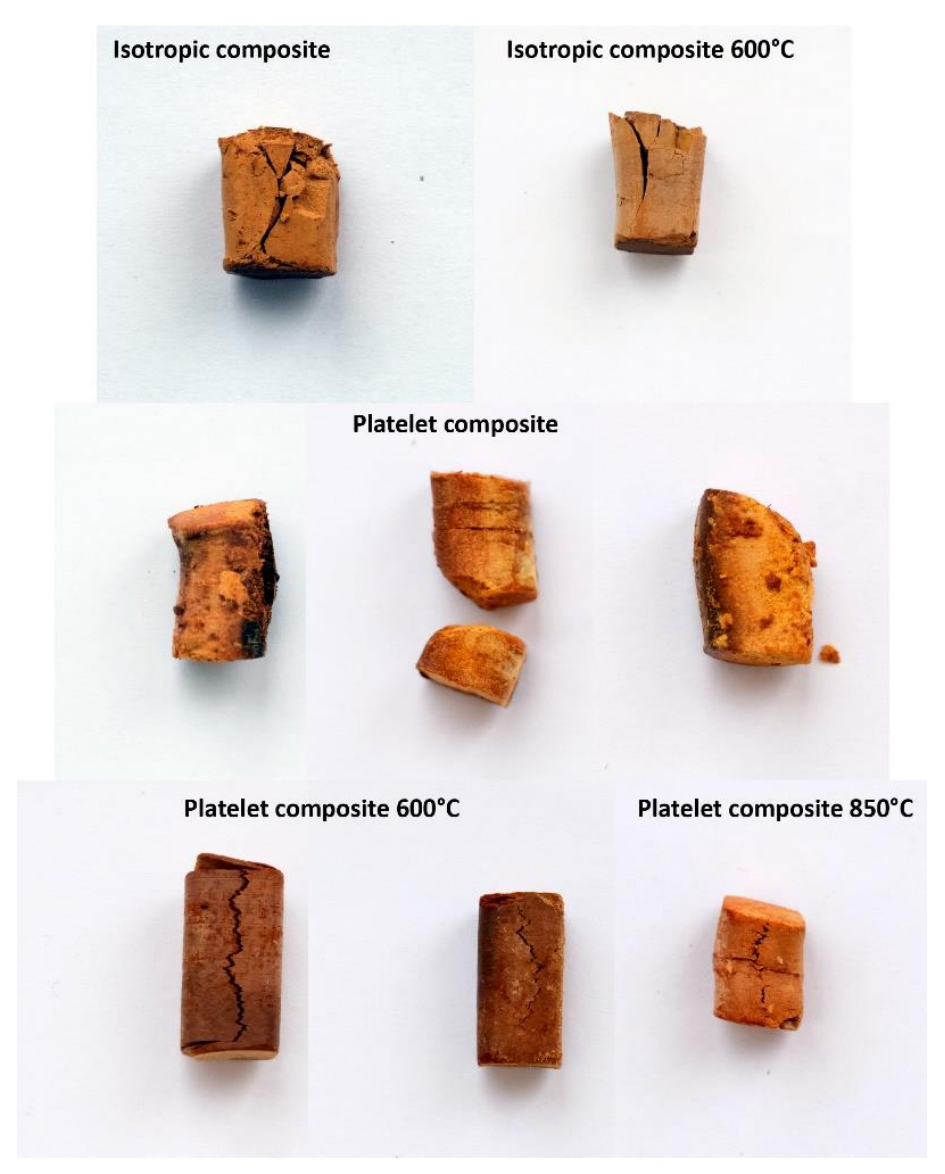

Figure S13. Photos taken of the different composites after the compression tests. A difference in the crack morphology is clearly visible when isotropic samples are compared with the platelet-structured samples. Moreover, the reduction in the elastic deformation during the compression of the monoliths for which the silica skeleton has been heat-treated can be clearly observed.

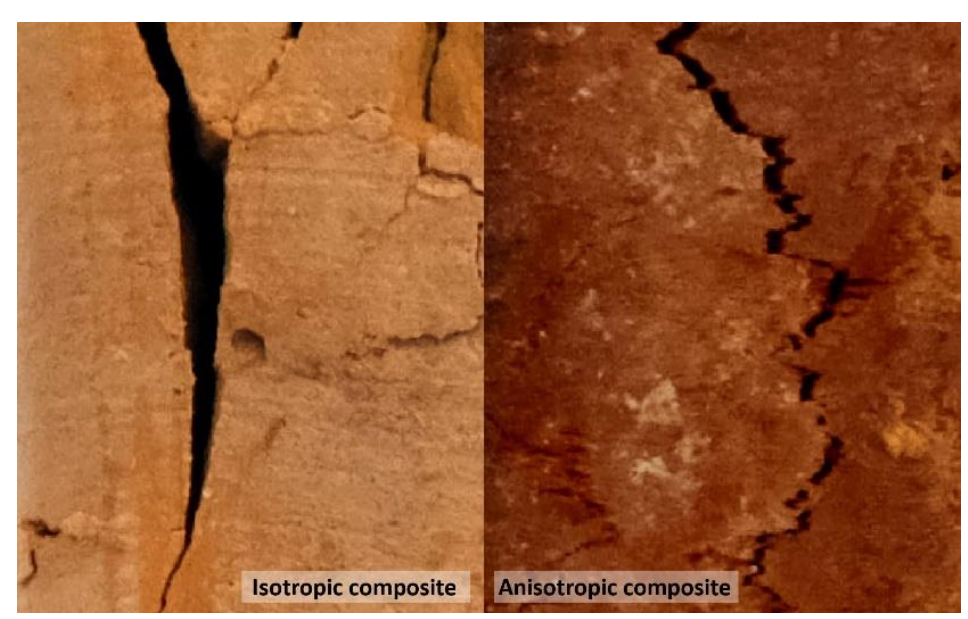

Figure S14. Crack morphology of an isotropic composite (left) compared to that of a composite mimicking nacre (right). The crack morphology in the isotropic samples is a straight vertical line compared to the zig-zag shape observed for the platelet-structured samples. In the latter case, the crack is deflected and winds its path between the individual platelets, leaving them intact. 

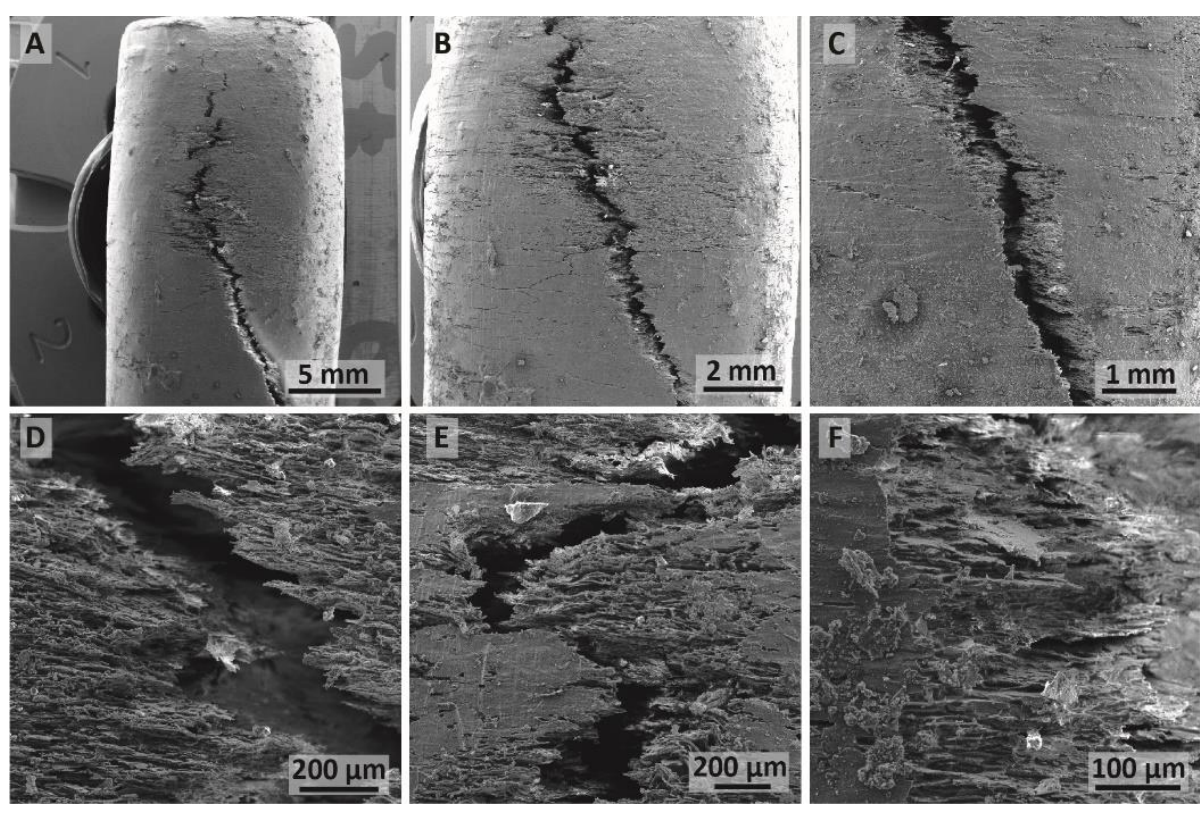

Figure S15. SEM images of the crack propagation after the compression of the composite heattreated at $600{ }^{\circ} \mathrm{C}$. The crack forms between platelets along the full length of the composite.

Table S4. Energy per unit volume calculations for every sample measured with dynamic mechanical testing. (A) Energy per unit volume for samples with isotropic structure. (B) Energy per unit volume calculated for all samples with isotropic structure and filled with polymer. (C) Energy per unit volume calculated from measured samples with platelet-structure. (D) Energy per unit volume calculated for samples with platelet-structure and filled with polymer.

\begin{tabular}{llll}
\hline Platelets & $\begin{array}{l}\text { Energy per unit } \\
\text { volume }\end{array}$ & Isotropic & $\begin{array}{l}\text { Energy per unit } \\
\text { volume }\end{array}$ \\
\hline 1 & 0.016 & 1 & 0.001 \\
\hline 2 & 0.009 & 2 & 0.004 \\
\hline 3 & 0.015 & 3 & 0.005 \\
\hline 4 & 0.023 & 4 & 0.0001 \\
\hline 5 & 0.004 & 5 & 0.002 \\
\hline 6 & 0.054 & 6 & 0.013 \\
\hline 7 & 0.010 & 7 & 0.003 \\
\hline 8 & 0.023 & 8 & 0.016 \\
\hline 10 & 0.009 & 9 & 0.002 \\
\hline 11 & 0.008 & 10 & 0.015 \\
\hline 12 & $3.040 \mathrm{E}-05$ & 11 & 0.005 \\
\hline $\boldsymbol{A V E R A G E}$ & 0.010 & & $\mathbf{0 . 0 0 6}$ \\
\hline Platelets & $\mathbf{0 . 0 1 5}$ & $\boldsymbol{A V E R A G E}$ & $\begin{array}{l}\text { Energy per unit } \\
\text { volume }\end{array}$ \\
\hline 1 & $\begin{array}{l}\text { Energy per unit } \\
\text { volume }\end{array}$ & Isotropic & 0.0002 \\
\hline 2 & 0.023 & with polymer & $9.516 \mathrm{E}-05$ \\
\hline 3 & 0.089 & 2 & 0.006 \\
\hline 4 & 0.021 & 3 & 0.003 \\
\hline 5 & 0.009 & 4 & 0.001 \\
\hline 6 & 0.026 & 5 & 0.007 \\
\hline 7 & 0.033 & 6 & 0.009 \\
\hline & 0.041 & 7 & \\
\hline
\end{tabular}




\begin{tabular}{llll}
\hline 8 & 0.028 & 8 & 0.005 \\
\hline 9 & 0.043 & 9 & 0.001 \\
\hline 10 & 0.008 & 10 & 0.011 \\
\hline 11 & 0.039 & 11 & 0.039 \\
\hline 12 & 0.013 & 12 & 0.007 \\
\hline 13 & 0.015 & & \\
\hline 14 & 0.003 & & $\mathbf{0 . 0 0 8}$ \\
\hline
\end{tabular}

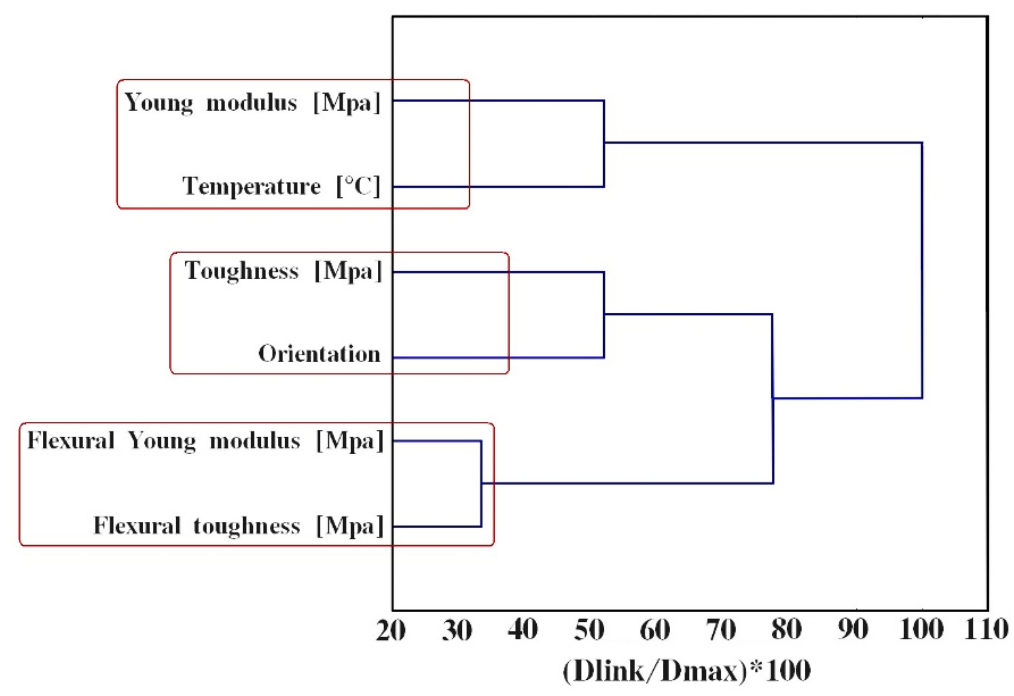

Figure S16. Hierarchical dendrogram for the clustering of the 6 variables, resulting in 3 clusters.

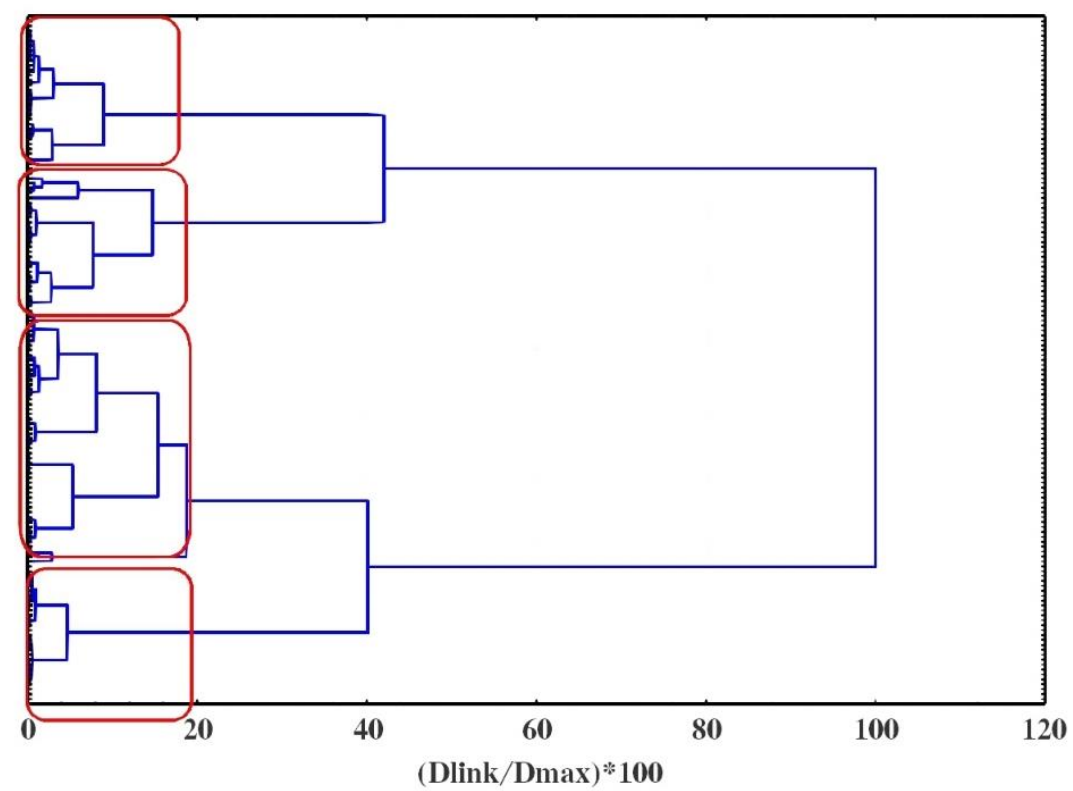

Figure S17. Hierarchical dendrogram for the clustering of the 139 objects of the data-set, resulting in four clusters. 
HCA is a well-known method for intelligent data analysis. It belongs to the non-supervised pattern recognition approaches, where the linkage between variables or objects of the system in study is spontaneously performed and the cluster significance is determined by some cut-off criterion, like Sneath's test $\left(1 / 3\right.$ or $2 / 3 D_{\max }$, where $D_{\max }$ is the maximal similarity calculated distance). Usually, before calculating the similarity between the objects of interest (typically by applying squared Euclidean distances as similarity measures), the raw data in the set are standardized to dimensionless values (by a z-transform procedure) to avoid deterioration of the clustering procedure caused by the differences in the variables' dimensions. An important stage is the selection of linkage procedure, which will make it possible to put the close objects into one similarity cluster. In our study the Ward's method of linkage was used.

Non-hierarchical (K-means) clustering is a typical representative of the supervised pattern recognition methodology where the number of clusters within the data set is a priori determined (in order to accept or reject some hypothesis). 4 clusters were a priori defined for our data set. K-means tries to assign $\mathrm{k}$ centers to represent the clustering of $\mathrm{N}$ points $(\mathrm{k}<\mathrm{N})$. The points are iteratively adjusted (starting with a random sample of the $\mathrm{N}$ points) so that each of the $\mathrm{N}$ points is assigned to one of the $\mathrm{k}$ clusters, and each of the $\mathrm{k}$ clusters is the mean of its assigned points. The output of this non-hierarchical approach is a table with the all the members of the analyzed data set attributed to the a priori identified cluster and the distances between the members within same cluster. The K means plot illustrates how variables are linked to the respective objects. The raw data set is used in the algorithm.

When we are running the two algorithms (HCA and NHCA) for a new dataset these two algorithms should be applied always stepwise. One should have in mind that we are searching for the best $\mathrm{K}$ (where the simpler approach is to assign the number of $\mathrm{K}$ obtained from $\mathrm{HCA}$ ) initial conditions. The other approach is to test randomly many iterations and trials and just to keep track and choose the best similarity pattern, according to the experimental observations. 
This is a very common solution with multiple initial conditions. At the end, we are obtaining the minimization the objection function and we have the more probable partitioning outcomes. The factor analysis (FA) is needed to determine the latent factors responsible for the split of the data set in groups of similarity. 
Table S5. Table of members inside each of the four clusters with their respective distance from cluster center calculated by K-means algorithm.

\begin{tabular}{|c|c|c|c|c|c|c|c|}
\hline \multicolumn{2}{|c|}{ Members of Cluster Number 1} & \multicolumn{2}{|c|}{ Members of Cluster Number 2} & \multicolumn{2}{|c|}{ Members of Cluster Number 3} & \multicolumn{2}{|l|}{ Members of Clustr Number 4} \\
\hline 38 cases & & 27 cases & & 28 cases & & 46 cases & \\
\hline Object & Distance & Object & Distance & Oject & Distance & Object & Distance \\
\hline isotropic 8505.03 & 0.757331 & isotropic 1.03 & 0.769611 & $\begin{array}{l}\text { Platelet } 600 \text { para } \\
5.04\end{array}$ & 0.25769 & isotropic 1.01 & 0.88999 \\
\hline isotropic 8505.05 & 0.681607 & isotropic 1.04 & 0.28229 & $\begin{array}{l}\text { Platelet } 600 \text { perp } \\
6.01\end{array}$ & 0.322794 & isotropic 1.02 & 0.865194 \\
\hline isotropic 8505.06 & 0.499717 & isotropic 1.07 & 0.462862 & $\begin{array}{l}\text { Platelet } 600 \text { perp } \\
6.02\end{array}$ & 0.436644 & isotropic 1.05 & 0.698292 \\
\hline isotropic 8505.07 & 0.423123 & isotropic 1.08 & 0.709655 & $\begin{array}{l}\text { Platelet } 600 \text { perp } \\
6.03\end{array}$ & 0.377419 & isotropic 1.06 & 0.887135 \\
\hline isotropic 8505.08 & 0.528813 & isotropic 1.10 & 0.711602 & $\begin{array}{l}\text { platelet } 600 \text { polymer } \\
\text { para } 8.1\end{array}$ & 0.359595 & isotropic 1.09 & 0.798304 \\
\hline $\begin{array}{l}\text { isotropic } 850 \text { polymer } \\
\quad 6.02\end{array}$ & 0.448698 & isotropic 1.11 & 0.273455 & $\begin{array}{l}\text { platelet } 600 \text { polymer } \\
\text { para } 8.2\end{array}$ & 0.421699 & isotropic polymer 2.05 & 0.804979 \\
\hline $\begin{array}{l}\text { isotropic } 850 \text { polymer } \\
\quad 6.03\end{array}$ & 0.447062 & $\begin{array}{l}\text { isotropic polymer } \\
2.01\end{array}$ & 0.261894 & $\begin{array}{l}\text { platelet } 600 \text { polymer } \\
\text { para } 8.3\end{array}$ & 0.401004 & isotropic 6003.03 & 0.652928 \\
\hline $\begin{array}{l}\text { isotropic } 850 \text { polymer } \\
\quad 6.05\end{array}$ & 0.44878 & $\begin{array}{l}\text { isotropic polymer } \\
2.02\end{array}$ & 0.229109 & $\begin{array}{l}\text { platelet } 600 \text { polymer } \\
\text { para } 8.4\end{array}$ & 0.208446 & isotropic 6003.04 & 0.968643 \\
\hline $\begin{array}{l}\text { isotropic } 850 \text { polymer } \\
\quad 6.06\end{array}$ & 0.448086 & $\begin{array}{l}\text { isotropic polymer } \\
2.03\end{array}$ & 0.632601 & Platelet 850 para 9.4 & 0.811512 & isotropic 6003.06 & 0.776464 \\
\hline $\begin{array}{l}\text { isotropic } 850 \text { polymer } \\
\quad 6.07\end{array}$ & 0.447949 & $\begin{array}{l}\text { isotropic polymer } \\
2.04\end{array}$ & 0.333792 & $\begin{array}{l}\text { Platelet } 850 \text { perp } \\
10.1\end{array}$ & 0.421078 & isotropic 6003.07 & 0.783596 \\
\hline $\begin{array}{l}\text { isotropic } 850 \text { polymer } \\
\quad 6.08\end{array}$ & 0.44825 & $\begin{array}{l}\text { isotropic polymer } \\
2.06\end{array}$ & 0.264636 & $\begin{array}{l}\text { Platelet } 850 \text { perp } \\
10.2\end{array}$ & 0.485391 & isotropic 6003.08 & 0.876604 \\
\hline $\begin{array}{l}\text { isotropic } 850 \text { polymer } \\
\quad 6.09\end{array}$ & 0.44809 & $\begin{array}{l}\text { isotropic polymer } \\
2.07\end{array}$ & 0.338446 & $\begin{array}{l}\text { Platelet } 850 \text { perp } \\
10.3\end{array}$ & 0.268165 & isotropic 6003.09 & 0.738579 \\
\hline $\begin{array}{l}\text { isotropic } 850 \text { polymer } \\
\quad 6.10\end{array}$ & 0.448095 & $\begin{array}{l}\text { isotropic polymer } \\
2.08\end{array}$ & 0.281284 & $\begin{array}{l}\text { Platelet } 850 \text { perp } \\
10.4\end{array}$ & 0.166673 & isotropic 600 polymer 4.01 & 0.72841 \\
\hline $\begin{array}{l}\text { isotropic } 850 \text { polymer } \\
\quad 6.11\end{array}$ & 0.448145 & $\begin{array}{l}\text { isotropic polymer } \\
2.09\end{array}$ & 0.28561 & $\begin{array}{l}\text { Platelet } 850 \text { perp } \\
10.5\end{array}$ & 0.17823 & isotropic 600 polymer 4.02 & 0.63689 \\
\hline $\begin{array}{l}\text { isotropic } 850 \text { polymer } \\
\quad 6.12\end{array}$ & 0.44811 & $\begin{array}{l}\text { isotropic polymer } \\
2.10\end{array}$ & 0.496378 & $\begin{array}{l}\text { Platelet } 850 \text { perp } \\
10.6\end{array}$ & 0.134351 & isotropic 8505.01 & 0.775162 \\
\hline $\begin{array}{l}\text { isotropic } 850 \text { polymer } \\
\quad 6.13\end{array}$ & 0.53828 & $\begin{array}{l}\text { isotropic polymer } \\
2.11\end{array}$ & 0.492094 & $\begin{array}{l}\text { Platelet } 850 \text { perp } \\
10.7\end{array}$ & 0.134686 & isotropic 8505.02 & 0.640799 \\
\hline $\begin{array}{l}\text { isotropic } 850 \text { polymer } \\
\quad 6.14\end{array}$ & 0.560436 & $\begin{array}{l}\text { isotropic polymer } \\
2.12\end{array}$ & 0.325157 & $\begin{array}{l}\text { Platelet } 850 \text { polymer } \\
\text { perp } 12.1\end{array}$ & 0.428111 & isotropic 8505.04 & 0.596845 \\
\hline platelet para 1.01 & 0.832652 & isotropic 6003.01 & 0.704455 & $\begin{array}{l}\text { Platelet } 850 \text { polymer } \\
\text { perp } 12.2\end{array}$ & 0.080754 & isotropic 8505.09 & 0.642093 \\
\hline platelet para 1.02 & 0.834368 & isotropic 6003.02 & 0.214789 & $\begin{array}{l}\text { Platelet } 850 \text { polymer } \\
\text { perp } 12.3\end{array}$ & 0.701461 & isotropic 8505.10 & 0.703353 \\
\hline platelet para 1.03 & 0.855788 & isotropic 6003.05 & 0.883499 & $\begin{array}{l}\text { Platelet } 850 \text { polymer } \\
\text { perp } 12.4\end{array}$ & 0.172365 & isotropic 850 polymer 6.01 & 1.043835 \\
\hline platelet para 1.04 & 0.864315 & $\begin{array}{l}\text { Platelet } 600 \text { para } \\
5.02\end{array}$ & 0.434706 & $\begin{array}{l}\text { Platelet } 850 \text { polymer } \\
\text { perp } 12.5\end{array}$ & 0.173494 & platelet perp 2.01 & 0.527767 \\
\hline platelet para 1.05 & 0.845413 & $\begin{array}{l}\text { Platelet } 600 \text { para } \\
5.04\end{array}$ & 0.547256 & $\begin{array}{l}\text { Platelet } 850 \text { polymer } \\
\text { perp } 12.6\end{array}$ & 0.376626 & platelet perp 2.02 & 0.557675 \\
\hline platelet para 1.06 & 0.858322 & Platelet 850 para 9.2 & 0.481078 & $\begin{array}{l}\text { Platelet } 850 \text { polymer } \\
\text { perp } 12.7\end{array}$ & 0.43586 & platelet perp 2.03 & 0.51918 \\
\hline platelet para 1.07 & 0.835133 & Platelet 850 para 9.3 & 0.724921 & $\begin{array}{l}\text { Platelet } 850 \text { polymer } \\
\text { perp } 12.8\end{array}$ & 0.12592 & platelet perp 2.04 & 0.578282 \\
\hline $\begin{array}{l}\text { Platelet para polymer } \\
3.01\end{array}$ & 0.677176 & $\begin{array}{l}\text { Platelet } 850 \text { polymer } \\
\text { para } 11.1\end{array}$ & 2.00122 & $\begin{array}{l}\text { Platelet } 850 \text { polymer } \\
\text { perp } 12.9\end{array}$ & 0.133346 & platelet perp 2.05 & 0.690106 \\
\hline $\begin{array}{l}\text { Platelet para polymer } \\
3.02\end{array}$ & 0.602007 & $\begin{array}{l}\text { Platelet } 850 \text { polymer } \\
\text { para } 11.2\end{array}$ & 0.430705 & $\begin{array}{l}\text { Platelet } 850 \text { polymer } \\
\text { perp } 12.10\end{array}$ & 0.170932 & platelet perp 2.06 & 1.362437 \\
\hline $\begin{array}{l}\text { Platelet para polymer } \\
3.03\end{array}$ & 0.621012 & $\begin{array}{l}\text { Platelet } 850 \text { polymer } \\
\text { para } 11.3\end{array}$ & 0.536681 & $\begin{array}{l}\text { Platelet } 850 \text { polymer } \\
\text { perp } 12.11\end{array}$ & 0.257724 & platelet perp 2.07 & 0.593334 \\
\hline Platelet 600 para 5.01 & 0.345411 & & & $\begin{array}{l}\text { Platelet } 850 \text { polymer } \\
\text { perp } 12.12\end{array}$ & 0.305753 & platelet perp 2.08 & 0.584375 \\
\hline Platelet 600 para 5.03 & 0.577065 & & & & & platelet perp 2.09 & 0.528403 \\
\hline $\begin{array}{l}\text { platelet } 600 \text { polymer } \\
\text { para } 7.1\end{array}$ & 0.741095 & & & & & platelet perp 2.10 & 0.652649 \\
\hline $\begin{array}{l}\text { platelet } 600 \text { polymer } \\
\text { para } 7.2\end{array}$ & 0.736843 & & & & & platelet perp 2.11 & 0.713378 \\
\hline $\begin{array}{l}\text { platelet } 600 \text { polymer } \\
\text { para } 7.3\end{array}$ & 0.565468 & & & & & platelet perp 2.12 & 0.593529 \\
\hline $\begin{array}{l}\text { platelet } 600 \text { polymer } \\
\text { para } 7.4\end{array}$ & 1.078125 & & & & & Platelet perp polymer 4.01 & 0.511005 \\
\hline Platelet 850 para 9.1 & 0.450503 & & & & & Platelet perp polymer 4.02 & 2.655865 \\
\hline $\begin{array}{l}\text { Platelet } 850 \text { polymer } \\
\quad \text { para } 11.4\end{array}$ & 1.606861 & & & & & Platelet perp polymer 4.03 & 0.50275 \\
\hline $\begin{array}{l}\text { Platelet } 850 \text { polymer } \\
\text { para } 11.5\end{array}$ & 1.177278 & & & & & Platelet perp polymer 4.04 & 0.844568 \\
\hline $\begin{array}{l}\text { Platelet } 850 \text { polymer } \\
\text { para } 11.6\end{array}$ & 0.691005 & & & & & Platelet perp polymer 4.05 & 0.907158 \\
\hline
\end{tabular}




\begin{tabular}{|c|c|c|c|}
\hline \multirow[t]{9}{*}{$\begin{array}{l}\text { Platelet } 850 \text { polymer } \\
\quad \text { para } 11.7\end{array}$} & 0.534426 & Platelet perp polymer 4.06 & 0.911354 \\
\hline & & Platelet perp polymer 4.07 & 1.355838 \\
\hline & & Platelet perp polymer 4.08 & 0.695129 \\
\hline & & Platelet perp polymer 4.09 & 1.081066 \\
\hline & & Platelet perp polymer 4.10 & 0.616083 \\
\hline & & Platelet perp polymer 4.11 & 0.956438 \\
\hline & & Platelet perp polymer 4.12 & 0.677607 \\
\hline & & Platelet perp polymer 4.13 & 0.577972 \\
\hline & & Platelet perp polymer 4.14 & 0.760829 \\
\hline
\end{tabular}

Table S6. Factor Loadings (Varimax normalized) (Marked loadings are >,700000)

\begin{tabular}{lll}
\hline \multicolumn{1}{c}{ Variables } & Factor $\mathbf{~ 1 ~}$ & Factor - 2 \\
\hline Young modulus $[\mathrm{MPa}]$ & 0,488 & $-0,463$ \\
\hline Toughness $[\mathrm{MPa}]$ & 0,269 & 0,740 \\
\hline Flexural Young modulus $[\mathrm{MPa}]$ & $-0,900$ & 0,053 \\
\hline Flexural toughness $[\mathrm{MPa}]$ & $-0,786$ & 0,172 \\
\hline Temperature $\left[{ }^{\circ} \mathrm{C}\right]$ & 0,864 & 0,178 \\
\hline Orientation & $-0,250$ & 0,842 \\
\hline Expl.Var \% & 42,400 & 25,600 \\
\hline
\end{tabular}

Two factors stand out, they explain almost $70 \%$ of the total variance of the system. The relationship between "flexural" variables is well defined (high factor loadings with negative sign); toughness and orientation are also well related in Factor 2. The temperature/ Young modulus link could be found in Factor 1 (mixed with the "flexural" factor) with positive factor loadings. It should be marked that Young modulus has not a very high loading and could be interpreted as member of Factor 1 close to Temperature (but opposite to the flexural parameters) or as member of Factor 2 but opposite to the orientation/toughness factor. Therefore, its link to temperature is the most significant. 
Table S7. Regression Summary Table for the dependent variable: Flexural toughness [MPa]

\begin{tabular}{|c|c|c|c|c|c|c|}
\hline \multicolumn{7}{|c|}{ Flexural toughness [MPa] (139 objects) } \\
\hline \multirow[t]{2}{*}{$R=0.72644511$} & \multicolumn{2}{|c|}{$\mathrm{R}^{2}=0.52772250$} & \multicolumn{2}{|c|}{ Adjusted $\mathrm{R}^{2}=0.5099677$} & \multicolumn{2}{|c|}{$F(5.133)=29.723 p$} \\
\hline & Beta & $\begin{array}{l}\text { Std.Err. } \\
\text { - of Beta }\end{array}$ & B & $\begin{array}{l}\text { Std.Err. } \\
- \text { of B }\end{array}$ & $\mathbf{t}(\mathbf{1 3 3})$ & p-level \\
\hline Intercept & & & 0 & 0.05 & 0 & 1 \\
\hline Young modulus [MPa] & 0.00227 & 0.072435 & 0.00227 & 0.07 & 0.03 & 0.97 \\
\hline Toughness [MPa] & -0.005453 & 0.06745 & -0.005453 & 0.06745 & -0.08 & 0.93 \\
\hline $\begin{array}{l}\text { Flexural Young } \\
\text { modulus [MPa] }\end{array}$ & 0.713622 & 0.08981 & 0.713622 & 0.08981 & 7.94587 & 0 \\
\hline Temperature $\left[{ }^{\circ} \mathrm{C}\right]$ & 0.035439 & 0.093875 & 0.035439 & 0.093875 & 0.37751 & 0.706397 \\
\hline Orientation & 0.124694 & 0.074889 & 0.124694 & 0.074889 & 1.665043 & 0.098258 \\
\hline
\end{tabular}

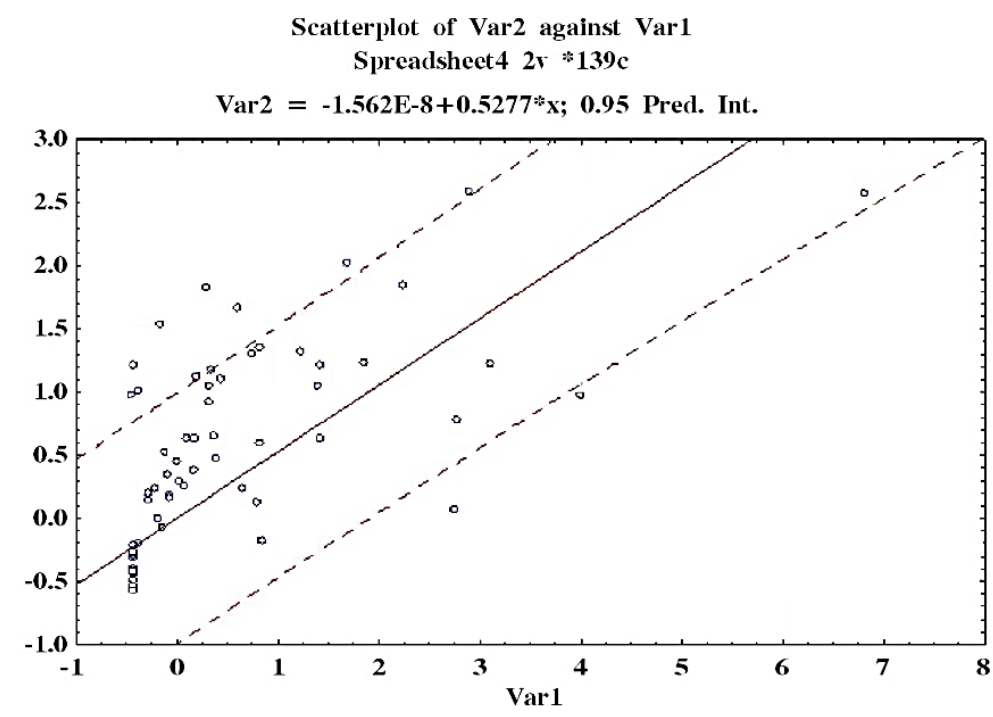

Figure S18. Multiple regression analysis plot. Best regression model for the relationships between the variables for a dataset of 139 objects.

Various combinations between dependent and independent variables, selected from the set of 6 variables, were checked and the best models (with respect to highest correlation between observed and predicted values of the dependent variable and best ANOVA results) were evaluated. 

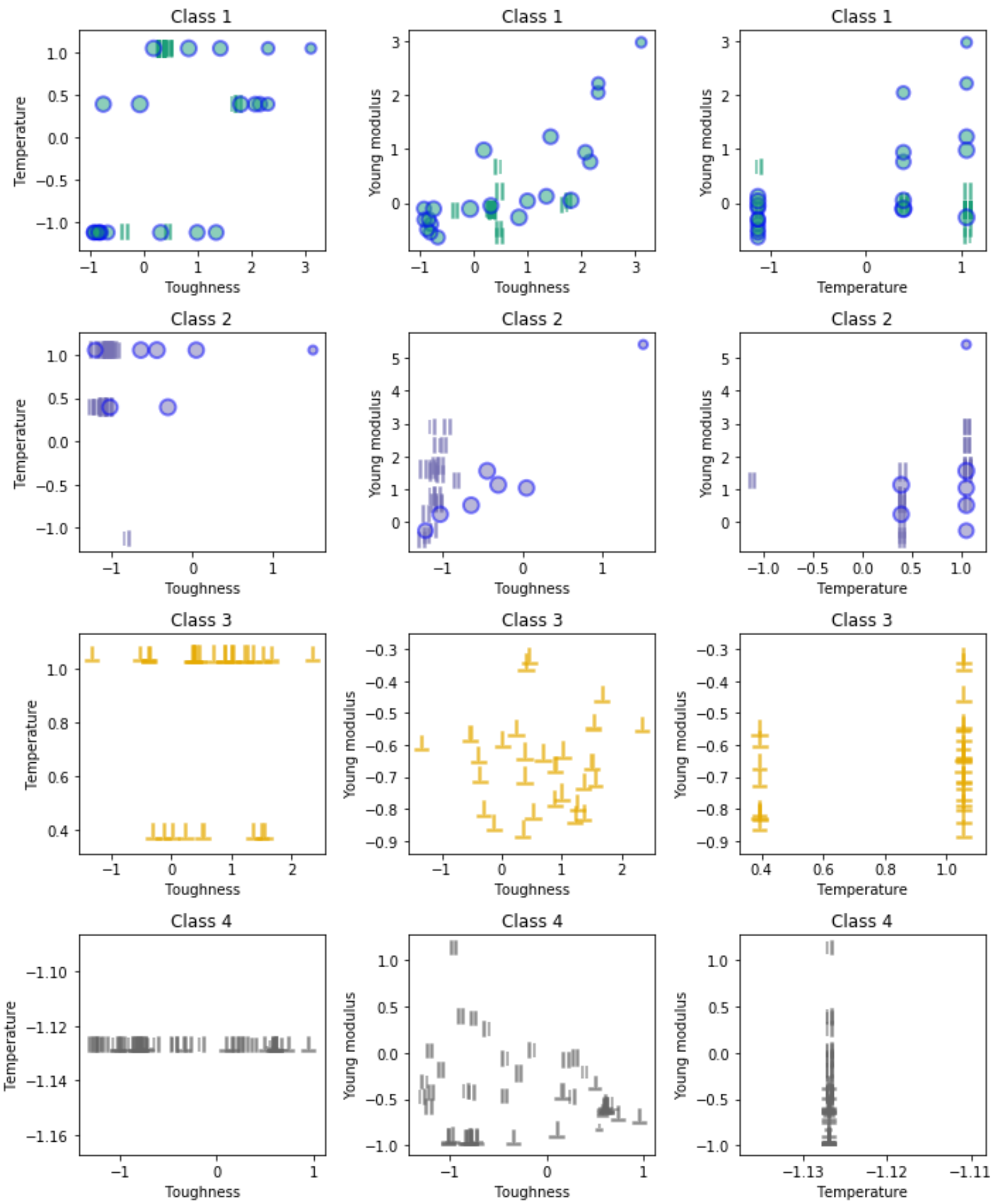

Cluster 1: orientation 0
Cluster 1 : orientation 1

Cluster 2: orientation 0 Cluster 3: orientation -1 $\frac{\mid}{\|} \begin{aligned} & \text { Cluster 4: orientation -1 } \\ & \text { Cluster 4: orientation } 1\end{aligned}$

Figure S19. 2D representation of the four clusters obtained by the K-means NHCA method showing one cluster per row of 3 plots. The objects are place within the axes by their distance obtained in the K-means plot. The samples within one cluster can be compared due to their mechanical properties. 
The classification procedure is based on distances obtained by the K-means clustering. However, the classification method distributes the objects differently within the clusters because, opposite to the K-means method, which forms clusters based on the calculated distance between the objects, the classification is based on distances between the variables related to the objects. In the $2 \mathrm{D}$ classification, within one cluster, the variables are classified two by two resulting in 3 classes. Inside the 3 classes that are given by the method, the objects related to the considered variables are represented based on normalized distances taken from the k-means algorithm. The obtained 2D projection of the classes represents the linkage between the mechanical properties and the structure of the respective monoliths. In the first row (class 1 down to class 4), comparing the four clusters allows to see that for a given temperature the perpendicularly oriented platelets and isotropic structured monoliths always depict higher toughness than parallelly oriented platelets. In the second row, the comparison of the different clusters allows the conclusion that isotropic structured monoliths are tougher than monoliths with parallelly oriented platelets, but except for one outlier, the parallelly oriented platelets are stiffer and show therefore higher Young modulus compared to the isotropic monoliths. The third row shows that an increase in temperature leads an increase in the Young modulus for the all the samples but for a given temperature, the compression of the platelets in the parallel orientation results in better mechanical resistance than in their perpendicular orientation.

Link 1. The source code for 3D-ploting based on K-Means is available on GitHub repository on the following link:

https://github.com/mici345/3D-ploting-K-Means/edit/main/3D\%20Classing\%20as\%20a\%20scatter\%20plot 